\title{
Mutual funds withdraw shield: performance or agency costs driver?
}

\author{
Carlos Alves* • Helena Mouta \\ CEF.UP, Faculty of Economics, University of Porto, Portugal \\ School of Technology and Management of Bragança, Portugal
}

Received: 17 February 2012

Revised: 26 March 2012

Accepted: 26 March 2012

\begin{abstract}
In this paper, using a unique database, we compare the performance of a set of equity mutual funds to a set of equity savings funds, which are similar to equity mutual funds in all but one characteristic: the tax regime that strongly penalizes withdrawals from equity savings funds. We found evidence consistent with the hypothesis that mutual funds less subject to liquidity shocks exhibit higher performances.
\end{abstract}

Keywords: mutual fund performance, withdrawals, liquidity shocks, fiscal policy JEL Classification Codes: G23, G28, H39

\section{Introduction}

In the past few decades, mutual fund performance has been under the constant scrutiny of both academics and practitioners. There has been ample discussion on whether some mutual fund managers achieve a persistently higher performance that justifies the higher costs of actively managed funds. Several empirical studies reject the existence of superior performance in mutual funds (e.g. Elton et al., 1996; Fletcher and Forbes, 2002), while many others support such a hypothesis (e.g. Grinblatt and Titmann, 1993; Otten and Bams, 2002).

However, there is scarce literature on the causes of abnormal performance, and in particular on the effect of inflows and outflows on mutual fund returns. There is consensus amongst researchers that capital fund flows are sensitive to past performances in developed markets (Goetzmann and Peles, 1997; Sirri and Tufano, 1998; and Christoffersen, 2001), but for a small market Alves and Mendes (2011), instead of the convex flow-performance relationship usually documented for the US, found an absence of reaction to past performance. There is also evidence that back-end load costs are an obstacle to performance reaction (Alves and Mendes, 2007).

*Corresponding author. E-mail: calves@fep.up.pt.

Citation: Alves, C. and Mouta, H. (2012) Mutual funds withdraw shield: performance or agency costs driver?, Economics and Business Letters, 1(1), 30-34. 
Nevertheless, there is limited research on the relationship between capital flows and mutual fund performance. Nanda et al. (2000) developed a model that sustains that mutual fund managers less subject to liquidity shocks exhibit higher performances. However, this theoretical prediction has not yet been found empirically.

Working with, as far as we know, a unique dataset, which includes a set of mutual funds that are subject to withdrawals and another set of mutual funds that are protected from withdrawals, we can directly evaluate the effect of potential liquidity shocks on mutual fund performance. Our database includes all equity funds (EF) that invest mainly in Portuguese stocks and all equity savings funds (ESF). These two types of mutual funds are equal in all but one characteristic: the tax regime that heavily penalizes withdrawals from ESF. The legal framework that supports ESF was created as an incentive to equity investing, during the privatization "boom" in the 1990s, when many state-owned companies were partially or totally sold on the Portuguese stock market. These ESF had important tax benefits that investors could only completely take advantage of for holding periods of 5 to 8 years. We must note that: i) this fiscal advantage is directly appropriated by the investor (not by the ESF); ii) there are no investment restrictions either for EF or ESF, except (for both) that they must invest mainly in Portuguese stocks; iii) given the small size of the Portuguese stock market, there are no differences of style (e.g. growth versus value) between these funds; iv) EF and ESF are managed by the same mutual fund companies and, given the small size of the Portuguese mutual fund industry, inside each company (presumably) by the same managers. This allows us to evaluate the effect of potential withdrawals, comparing the performance of the two groups.

The peculiarities of ESF can lead to different expectations regarding their performance when compared to equity funds. Given the nature of ESF tax benefits, investors will not normally withdraw money from them, since that would lead to the loss of those benefits. Therefore, ESF have lower liquidity needs. This means that ESF managers do have more resources available to invest in higher return securities than EF managers, which would lead us to expect better ESF performances («liquidity hypothesis»). However, this protection from withdrawals may have a perverse effect. In fact, ESF investors are discouraged to move away from poor performers given the strong tax disadvantage on withdrawals, and thus the fund managers will not be penalized for poor performances. This can induce managers to act in their own interest or in the interest of the company to which they belong. If this effect is dominant, we would expect ESF to exhibit poorer performances than EF («agency costs hypothesis»).

\section{Data and methodology}

Our sample includes a total of $30 \mathrm{EF}$ - all Portuguese open-end mutual funds which were classified as "domestic equity funds" by APFIN" ${ }^{1}$ - and 17 ESF - all "equity savings funds" in existence -, between 31st December 1993 and 31st December 2004, and is therefore identical to the population. ${ }^{2}$ The daily data for each fund is from DATHIS. ${ }^{3}$ All funds in existence for all or part of the period were included in the sample, and thus our sample is free from survivorship bias.

\footnotetext{
${ }^{1}$ APFIN is the Portuguese association of mutual fund management companies.

2 The special tax regime for ESF ended on 31st December 2004. Therefore, we cover the entire period during which this regime was in force.

${ }^{3}$ Financial information disclosure service of Euronext Lisbon.
} 
We use three different measures of performance: abnormal cumulative returns $(\mathrm{ACR})^{4}$, risk-adjusted excess returns (alpha) using one-factor CAPM and risk-adjusted excess returns using Carhart's (1997) four-factor model. The analysis is conducted on both sets of funds and we then compare the two sub-samples in order to determine whether ESF and EF have different performances.

\section{Analysis and results}

i) Analysis of Betas

The average EF betas are lower, both in bull and bear years (see Table 1). This could be explained by the fact that ESF are not subject to frequent withdrawals, the managers of these funds not being subject to liquidity shocks. Thus, they can invest a higher proportion of their portfolios in stock. EF, on the other hand, need to allocate part of their portfolios to liquid assets, which have betas of around zero.

Table 1. Average Betas

\begin{tabular}{|c|c|c|c|c|c|c|}
\hline & \multicolumn{3}{|c|}{ CAPM Model } & \multicolumn{3}{|c|}{ Carhart Model } \\
\hline & $\mathbf{E F}$ & ESF & ESF-EF & $\mathbf{E F}$ & ESF & ESF-EF \\
\hline \multicolumn{7}{|l|}{ Bull Years } \\
\hline Average & 0.60 & 0.74 & $0.14^{* * *}$ & 0.59 & 0.74 & $0.14^{* * *}$ \\
\hline Standard Deviation & 0.21 & 0.07 & $0.14^{* * * *}$ & 0.22 & 0.07 & $-0.14^{* * *}$ \\
\hline \multicolumn{7}{|l|}{ Bear Years } \\
\hline Average & 0.45 & 0.78 & $0.33^{* * *}$ & 0.38 & 0.75 & $0.33^{* * *}$ \\
\hline Standard Deviation & 0.23 & 0.04 & $-0.20^{* * * *}$ & 0.22 & 0.05 & $-0.20^{* * *}$ \\
\hline \multicolumn{7}{|l|}{ Entire Period } \\
\hline Average & 0.54 & 0.75 & $0.21^{* * *}$ & 0.51 & 0.74 & $0.21^{* * *}$ \\
\hline Standard Deviation & 0.22 & 0.06 & $-0.16^{* * *}$ & 0.24 & 0.06 & $-0.16^{* * *}$ \\
\hline
\end{tabular}

Obs.: (i) In this table we present the average EF and ESF betas (i.e. the market excess return coefficient) calculated using one year of past returns, with CAPM and Carhart Models; (ii) the market return proxy was the PSI General index (the Euronext Lisbon general index); (iii) Bull market years were defined as years when the value of the PSI General index at the end of the year was higher than its value at the beginning of the year, while bear market years were defined as years when the value of the PSI General index at the end of the year was lower than its value at the beginning of the year; (iv) The symbol *** shows statistical significance at the 0.01 level for the t-test of equal means (equal variances not assumed) and the test of homogeneity of variance (Levene Statistic) based on the mean.

The ESF betas have lower variability, and this is confirmed by Levene's test of homogeneity of variances. Thus, ESF managers seem to target betas and stick to that target, rather than dramatically changing the risk level of their portfolios according to market fluctuations. A t-test of equal sample means provides similar conclusions: average betas are higher for ESF than for EF (one percent significance level).

\section{ii) Analysis of Performance}

For each type of fund, we computed the average performance of portfolios constructed in two distinct ways. Firstly, all existing funds at the end of each quarter were assigned the same weight (EW). Secondly, the weight of each fund was assumed to be the weight of the fund's net asset value in the total net asset value of all within the same category

\footnotetext{
${ }^{4}$ The daily abnormal return is the difference between each fund's daily return and the market daily return (proxied by the PSI General index). The cumulative abnormal return is the sum of the daily abnormal returns.
} 
and do not support the agency costs hypothesis. They also support the thesis according to which mutual fund managers less subject to liquidity shocks, such as the ESF managers, will exhibit higher performances.

Our results also support tax policies that require longer investment horizons.

\section{Acknowledgements}

CEF.UP is supported by CFT through POCTI of the QCAIII, which is financed by FEDER and Portuguese funds.

\section{References}

Alves, C. and Mendes, V. (2007) Are mutual funds investors in jail?, Applied Financial Economics, 17, 1301-1312.

Alves, C. and Mendes, V. (2011) Does performance explain mutual fund flows in small markets? The case of Portugal, Portuguese Economic Journal, 10, 129-147.

Carhart, M. (1997) On persistence in mutual fund performance, Journal of Finance, 52, 57-82.

Christoffersen, S. (2001) Why do money fund managers voluntarily waive their fees?, Journal of Finance, 56, 1117-1140.

Elton, E., Gruber, M. and Blake, C. (1996) The persistence of risk-adjusted mutual fund performance, Journal of Business, 69, 133-157.

Fletcher, J. and Forbes, D. (2002) UK unit trust performance: does it matter which benchmark or measure is used?, Journal of Financial Services Research, 21, 195218.

Goetzmann, W. and Peles, N. (1997) Cognitive dissonance and mutual fund investors, Journal of Financial Research, 20, 145-158.

Grinblatt, M. and Titmann, S. (1993) Performance measurement without benchmarks: an examination of mutual fund returns, Journal of Business, 66, 47-68.

Nanda, V., Narayanan, M. and Warther, V. (2000) Liquidity, investment ability, and mutual fund structure, Journal of Financial Economics, 57, 417-443.

Otten, R. and Bams, D. (2002) European mutual fund performance, European Financial Management, 8, 75-101.

Sirri, E. and Tufano, P. (1998) Costly search and mutual fund flows, Journal of Finance, $53,1589-1622$. 